doi: 10.19090/i.2018.29.176-191

UDC: $821.14^{\prime} 02-2$

ISTRAŽIVANJA

JOURNAL OF HISTORICAL RESEARCHES

29 (2018)
ORIGINAL SCIENTIFIC PAPER

Received: 13 March 2018

Accepted: 9 July 2018

\title{
GORDAN MARIČIĆ
}

University of Belgrade

Faculty of Philosophy, Department of Classics

gmaricic@f.bg.ac.rs

\section{IFIGENIJA RADULOVIĆ}

University of Novi Sad

Faculty of Philosophy, Department of History

ifigenija@ff.uns.ac.rs

\section{JELENA TODOROVIĆ}

University of Belgrade

Faculty of Philosophy, Department of History

jekutic@gmail.com

TWO RADIO DRAMAS OF LOVE, HATE AND REVENGE

\begin{abstract}
The topic of this paper is an ancient and everlasting story of love, hate, and vengeance. This archetypal narrative was recreated and staged in the 1960s in the form of two radio dramas by two Serbian (at the time Yugoslav) playwrights Jovan Hristić and Velimir Lukić. By means of those plays the two renowned scholars and playwrights achieved the revival of the previously mentioned ancient myth in the contemporary circumstances and rewrote the old story using modern features and language.
\end{abstract}

Keywords: ancient myth, love, hate, revenge, radio drama, Orestes, Medea.

\section{Introduction}

Tovan Hristić (b. 1933, d. 2002) and Velimir Lukić (b. 1936, d. 1997) are distinct drama representatives belonging to the well-known group of Serbian playwrights with a characteristic reflexive-poetic orientation, who emerged in the 1960s and enriched Serbian dramatic literature with a new approach to the world based on the relocation of the ancient myths in the contemporary reality and on the rational analysis of the burning social and moral issues of their times. At the time Yugoslavia was already open to the West and 
published literary works which appeared to be radically detached from the doctrine of Socialist Realism. Those were the years when the ruling ideology discreetly but consistently began to support modern tendencies in all art forms. Orestes and Medea are plays that were "above" the problems imposed by everyday life and did not openly criticize phenomena of the contemporary society.

By the time Hristić's and Lukić's first plays were staged at the theatres of Belgrade, dramas based on ancient myths had already been written ${ }^{1}$ in Yugoslavia by authors like: Marijan Matković (Prometej [Prometheus], 1952, Heraklo [Hercules], 1957), Dominik Smole (Antigona [Antigone], 1959), Miroslav Krleža (Aretej ili legenda o svetoj Ancili, rajskoj ptici [Aretaeus, or the Legend of St. Ancilla, the Bird of Paradise], 1959), etc.

Coming from a similar educational background, both Jovan Hristić and Velimir Lukić attended the prestigious Second Belgrade Gymnasium and then studied philosophy. However, while Hristić graduated from the Department of Philosophy, Lukić received his degree in Dramaturgy. Jovan Hristić was a poet, dramatist, essayist, literary and theatre critic, translator, professor at the Faculty of Dramatic Arts and the head of the Serbian Literary Association as well as of the Serbian PEN centre. ${ }^{2}$ Charles Simic wrote in a blurb of the front dust jacket of Hristićs 2003 radio drama edition that "Jovan Hristić is perhaps the last great Eastern European poet who is completely unknown in the West. One may say of him, what Auden said of Cavafy, that his attitude toward the poetic vocation was the one of an aristocrat. He wrote as if ancient Greek and Roman poets were his contemporaries. A wise man living in troubled times; he left us poems of extraordinary eloquences and great beauty."3

Velimir Lukić wrote poems along with dramas and in the period of eighteen long years he served as the director of the National Theatre in Belgrade as well as the artistic director of the prestigious Belgrade theatre-Atelje 212.

Both those playwrights started out writing poetry, together with Borislav Radović, as members of the same Literary Society of the Second Belgrade Gymnasium. They were close friends who admired poets like Elliot, Spender, Hugh Auden, Mallarmé, and Baudelaire and it was their poetry that propelled them to drama. Due to this specific poetic heritage, Jovan Hristić and Velimir Lukić imposed themselves as mature authors of

\footnotetext{
${ }^{1}$ As Gilbert Highet 1985: 532-533 writes in his book The Classical Tradition, Greek and Roman influence on Western Literature, (chap. The Reinterpretation of the Myths): "Also, since the French intellectuals are always defending themselves against the Olympians, Gide and Cocteau and the others find a certain relief in humanizing, debunking, and even vulgarizing some of the formidable old traditions. By bringing the myths nearer to humanity they make them more real. On the other hand, they also find the myths to be an inexhaustible source of poetry. One of the gravest defects of modern drama is that it lacks imaginative power. It is quick, clever, sometimes thoughtful, always realistic. But the great dramas of the world do not stay on the ground. They leave it and become poetry. Because of the modern world's emphasis on material power and possessions it is extremely difficult to write a contemporary play which will rise, at its noblest moments, into poetry; but contemporary problems, treated as versions of Greek myths, can be worked out to solutions which are poetic, whether the poetry is that of fantasy or that of tragic heroism.".

${ }^{2} \mathrm{He}$ was also a candidate for the Serbian Academy of Sciences and Arts. Unfortunately, neither the credibility, nor the authority of three respectable academicians, Predrag Palavestra, Matija Bećković and Ljubomir Simović, not to mention their excellent-introductory report, did help. Jovan Hristić never became even a corresponding member of the Serbian Academy

${ }^{3}$ Hristić 2003: front dust jacket of the book.
} 
neoclassical provenence ${ }^{4}$ which was obvious from their very first plays.

It is interesting and most likely a mere coincidence that both playwrights wrote radio dramas with the same subject of taken and untaken revenge in two years' lapse. But is it also a coincidence that both of them were inspired by the ancient myth? It is also worth mentioning that Jovan Hristić wrote two more dramas inspired by Greek myths ${ }^{5}$ : Ciste ruke (Clean Hands) in 1960 and Sedmorica: kako bismo ih danas čitali (The Seven, and How We Would Read Them Today) in 1969, while Velimir Lukić wrote a few more dramas with classical motifs: Okamenjeno more (The Petrified Sea in 1962), Dugi život kralja Osvalda (The Long Life of King Oswald in 1963), I smrt dolazi na Lemno (Death Also Comes to Lemnos in 1970), Zavera ili dugo praskozorje (Conspiracy or the Long Daybreak in 1974), Zla noć (The Evil Night in 1976) and Tebanska kuga (The Theban Plague in 1987). ${ }^{6}$

However, in the two dramas in question, Orestes and Medea, this taken and untaken revenge premise is marked by the dominant motif of a love-hate relationship.

We have to bear in mind here that a radio drama is deprived of the visual effect. Instead of the visual impact that an image conveys, a radio drama is entirely contained in the verbal expression, in the one or two silent pauses, as well as in the music that underlines its atmosphere in a discrete manner. "The verbal theatre of Jovan Hristić and Velimir Lukić has thus entered this media's very dimension without any difficulty, being enveloped within the well-known mythical story (either destroying or recreating it)." 7

Jovan Hristić was penniless when he was discharged from the army and one day he bumped into the editor ${ }^{8}$ of the radio program of the Belgrade State Radio, who suggested that he should write a radio drama. Jovan Hristić did so. The resulting drama, Orestes, was written ${ }^{9}$ almost as a pre-ordered text and won Sterija's prize in 1961 and three years later the

\footnotetext{
${ }^{4}$ Marjanović 1998: 93.

${ }^{5}$ Several decades later, in the 1990s, in Serbia appeared several young authors who - under the pressure of the war and turmoil that were raving over the territory of former Yugoslavia - once again reached out to the ancient myths and motifs. Miomir Petrović, a playwright and author of a drama with an ancient motif entitled The Argive Incident, in the Serbian playwrights of the $20^{\text {th }}$ century analyzed and explained his dramaturgical approach, as well as those of his fellow colleagues, especially the ones inclined towards ancient myth and antiquity in general, such as Boško Milin in Ad Kalendas Graecas, Ivan Panić in The Testament of Socrates and Gordan Maričić in Brutus. He says that "now at the end of the century, domestic playwrights once again turn towards the Serbian heroic Epics and its monarchist past. After whatever disputably ethical in them turned into elements equally powerful as aesthetical, there would appear, as Petrović believes, polemic or anti-mythical dramas with ancient topics, the ones referring to Kosovo and other archetypes, which would be highly ranked in the Serbian dramaturgical literature. Such dramas, just as those of Jovan Hristić and Velimir Lukić, will win their originality in spite or rather just because of the mythical membrane which wraps them," Marjanović 1997: 205.

${ }^{6}$ In the interview "Generacija darovitih reditelja" (Generation of Talented Directors) of the daily newspaper Politika (20 Jun 1998) p. 17, Jovan Hristić answered Zoran Radisavljević's question: "Much has been said on introducing the myth into drama. There is a master thesis which analyzes the use of ancient myth in contemporary drama and a dissertation is being prepared on the same topic. Ancient myths have been in use since the $16^{\text {th }}$ century. For some period of time they were the common languages of the educated classes. To be honest, we (sc. in Yugoslavia) have no tradition of using the ancient myth to convey messages. In our milieu Velimir Lukić and I started using it and this attracted more attention than it deserved. In France for example, there are many dramas that use ancient mythology. Ancient myths are perfect tales to support various different interpretations."

${ }^{7}$ Maričić 2006: 586.

${ }^{8}$ Steva Majstorović.

${ }^{9}$ Hristić reveals how this radio drama was written in his "Skica za fotobiografiju": 119.
} 
prize for a best stage performance of the National Theatre of Croatia in Zagreb. The impact this radio drama had on the social and cultural life of the time echoes in the report written on the occasion of Jovan Hristićs candidacy ${ }^{10}$ for a corresponding member of the Serbian Academy of Science and Arts: "This tragedy exists beyond time and space, immanent to the very core of human nature. Being the scene of intellectual paradoxes and moral clashes, Hristić's play may indeed look somehow apocryphal but only in relation to myth and history, whose material the playwright uses as his handy solution, a well-known and exhaustively examined tool. With regard to the literary and theatrical qualities his dramas have authentic values. They introduce modern and unconventional poetical dramaturgy into Serbian drama and an uncommon, extraordinary and untraditional concept of the theatre and its function, namely the concept of theatre and its roles, with their primary concern being to use theatre as a grandstand for poetic transposition of philosophical attitudes and beliefs."11

Velimir Lukić, on the other hand, did not deny that his plays indeed deal with a domestic and global situation. If not political, neoclassical dramas are mere comments. ${ }^{12}$ Velimir Lukić says that we look upon them in two ways. In the first perspective, for instance, we recognize an ancient story and in the second one we perceive the way the writer interprets it. ${ }^{13}$

\section{From mythical times to our ears}

The use ${ }^{14}$ of Greek mythology serves contemporary writers and artists in many ways. Most importantly “...the myth enjoys a unique existence outside the flux of time, its aesthetic images are not bound to time and space. Such elasticity allows modern dramatists to create events and characters that are believable and relevant to contemporary experience. Once the situations around which the ancient tales spin are abstracted, they are found to be of general interest and significance. The Orestes myth, to give one example, reduces itself to the tale of a man who returns home after an absence of a number of years, sets right an old grievance within his house and departs again. Starting with this bare outline, the modern artist begins to add certain elements which result in creating an entirely new view of the hero's experience." 15

\footnotetext{
${ }^{10}$ See note 2 above.

${ }^{11}$ Predrag Palavestra, Matija Bećković, Ljubomir Simović, Čini nam čast i zadovoljstvo... (It is Our Honor and Pleasure...), on the Assembly for the inauguration of new members for the Serbian Academy of Science and Arts, Language and Literature Department.

${ }^{12}$ Some critics, one way or another, found political implication in Hristić's dramas (see among others: Marjanović 1997: 189).

${ }^{13}$ This interpretation, according to Hristic (1969: 200-201), is what we see as comments of the ancient tale which is in the background. "We do not experience it as something that is going on, in front of us, in its physical concreteness and obviousness, we experience it as something uttered and said afterwards. The Antigone of Anouilh is never alone in the scene, behind her (and the drama itself) there is always Sophocles' Antigone, and she (it) exists only in this relation."

${ }^{14}$ Jovan Hristić himself explains in his article "Antički mit i savremena drama" (Ancient and Contemporary Drama): "Myth is an instrument of exploring human fate: a constant of innumerous varieties of life that we see around us; a formula by which the meaning, that, we believe, is writer's task, could be revealed." p. 199.

${ }^{15}$ Belli 1969: 185.
} 
Hristić's drama Orestes begins when the hero comes to Mycenae. Orestes faces his action provoked by the crime of the others', a crime which is meant to become his own. The situation in the drama takes place in the present tense, but it is the past that determines it and the future that is announced. It is independent from the hero's character, imposed in a completely new way from the outside. ${ }^{16}$ At her home, which became the palace of her stepfather and mother, Electra works hard as if she were a servant, not complaining at all, utterly devoted to memories and oblivion of her past life. She neither hates them nor is she hurt by her mistreatment. On the other hand, Clytemnestra acts as an evil stepmother while waiting to be sure that the child her daughter carries is not Aegisthus'; the child that is supposed to give meaning to her life. Aegisthus is constantly hot and cares for nothing else but for a bath in order to cool down a bit. Pylades and Orestes arrive in Argos as voluntary refugees. Pylades has already brought into question the justification of Orestes' revenge. The girl, Electra's fellow sufferer, recognizes Orestes and lets him secretly into the palace. Electra sways Orestes by her recollections of Agamemnon:

ELECTRA: Do you remember them, Orestes? Do you remember them the way I remember him? I

loved him, while you hated them. Love remembers for a lifetime, while hate only for an act. ${ }^{17}$

Similarly as in Hristić's first drama Clean Hands, where Oedipus represents a modern hero with humane tendencies, whose main goal is to stay clean no matter what misery and humiliation of life he suffers, as well as to stay distant from any kind of human necessity, in this drama Orestes also decides to stay innocent, in Rousseau's sense. He is not capable of taking revenge for his father's death. By doing so he would violate the moral balance of the world whose inviolability Orestes cares so much for. ${ }^{18} \mathrm{He}$ does not kill Clytemnestra and Aegisthus since they are not what they used to be seven years ago. Instead, time has taken its revenge instead of him. ${ }^{19}$ This is so vividly described and yet again hidden in Orestes' words that follow. After having finished their breakfast, he and Pylades start off for another tour of Greece, while Aegisthus takes his bath. The tragic situation is overcome by the very character of Orestes and with the help of the dialogue illustrating how time alters and erases memories and events that are recorded by our conscience: ${ }^{20}$

\footnotetext{
${ }^{16}$ Kott 1974: 249-250.

${ }^{17}$ Hristić 1970: 112. All the translations of the lines, verses and quotations into English are of the authors unless it is differently noted.

${ }^{18}$ Cf. Finci 1965: 281-282.

${ }^{19}$ Similar are the views of the above mentioned Eli Finci: "The motifs of quitting revenge, given by Hristić only very summarily, I would say... are not of human order, have no psychological interference, but are entirely of moral and intellectual order. There are several motifs, clearly defined and interwoven, which would be enough, any of them taken separately - to disturb Orestes' easily taken decision and his mentioned loose passion for justice. I would excerpt two amongst them, since I believe they are important for Hristić's moral contemplation: the first (motif) is that the assassins (...) are not what they appear to be seven years after they had committed the crime and the vengeance would only do harm to other people (the sense of time as the essential component of human existence) and the second (motif), the moral deed of vengeance cannot change anything since the killed has gone for good (sense of inviolability of life hierarchy as it is), the belief that a human cannot change anything by his action even if he wants to." ibid.

${ }^{20}$ As Kott sees it, the tragedy is determined by the situation and not by the characters such as Antigone, Oedipus
} 
ORESTES: There are so many towns that we do not recognize. Our memory is vivid at times, but then again it fades. We go on and forget, and come back again. Still, places are always different, yet always resembling one another. ${ }^{21}$

Hristić's Electra is quite extraordinary. She has nothing to do with her original counterpart in Aeschylus or Euripides. She is neither stirred nor put into motion by her vengeful urge. In Hristić's adaptation, she "turned into a resigned shadow living in memories, reminiscence, showing interest only in routine quotidian matters." 22 Electra no longer hates, she only remembers her love for her father and does not want Orestes to destroy himself by submission to the laws of the myth. By observing Aegisthus and Clytemnestra gradually turning from tragic criminals into a middle-aged disintegrated couple, in despair - turning from figures of action into those who have slowly become subjugated to the time that destroys them by its mere flow and reminds them of the crime they committed - Electra is the first one to understand the fact that neither she nor Orestes would have gained a thing by the very act of revenge. In a couple of scenes dedicated to Clytemnestra and Aegisthus, Hristić completed the psychological portrait of those who contemplated revenge for seven years with the psychology of the people whose conscience is guilty of a crime and had been doing nothing but waiting for revenge to come for seven long years. ${ }^{23}$ At the beginning of the drama, Hristić's Orestes is still eager to be a genuine avenger, similar to Orestes in classical tragedies. Nevertheless, he is not the kind of man who easily decides to commit a murder, in the same fashion that Hamlet is not. Through the conversation with Pylades and Electra and the contemplation of a bloody deed, he sees that by committing it, he himself would become like Aegisthus. In the final stage, upon reaching his maturity, Orestes becomes a character capable of manipulating the myth. Contrary to the classical tragic poets who portray Clytemnestra as a murder accomplice, Hristić categorically states that she is the one and only murderer. Seven years later, she is tired of past, indifferent towards life, desperately looking for something that would help her continue living. Aegisthus has gained weight and shrunk, his hair is no longer black and he shaves his beard. He constantly takes baths, enjoys his breakfasts and wine, too. Clytemnestra and Aegisthus, the royal couple sullied by crime, are no more than mere shadows of the people they used to be. Hristic deals with them approximately as much as he deals with Orestes and Electra. Aeschylus' and Sophocles' tragedies were focused on the brother and sister - the avengers. Aegisthus and Clytemnestra were only superficially depicted in them, through the emphasis of those features that incited the audience to hate them, in order to justify their slaughter. "However, Hristić resorted to an inverse treatment: not only did he achieve to justify the act of revenge at the end of the drama, but to reaffirm his principal idea through the analysis of Clytemnestra and Aegisthus contained in the fact that revenge was unnecessary since the crime itself against Agamemnon has, for seven long

\footnotetext{
or Orestes. The situation is independent even from the dialogue itself. The dialogue serves only to inform us about the entire situation. V. Kott 1974: 250.

${ }^{21}$ Hristić 1970: 113.

${ }^{22}$ Frajnd 1971: 350 .

${ }^{23}$ Ibid.
} 
years, been subsequently performed even before Orestes stepped in." 24

Hristić's characters reject the heroic and mythical dimension through their common daily routine - dealing with trivial activities of the household such as washing the dishes, making the bed, having breakfast, taking a bath. Those usual activities replace the extreme ones: murder, revenge, heroic deeds. Even conversations on revenge are reduced to the real, quotidian, almost "domestic" life. Thus, the mythical values are being persistently and faithfully twisted in a non-intrusive manner.

Silences, or more precisely, pauses in conversation, are not only absent after the exchange of lines, ${ }^{25}$ but characters quite often remain silent in the course of their own lines. All those pauses represent important parts of the text. They appear either when the dramatic tension grows, or when the preceding sentence is marked by some kind of pathos or a tragic tone. Silences make these elements wane and fade without leaving an echo. In this way Hristic diminishes tragic and heroic elements in the drama and we again find those quotidian and real-life features predominantly dispossessed of pathos. Consequently, the final catastrophe seems like a natural, logical and unique outcome of the drama, although in utter contrast to the classical myth and Orestes' intentions. Jovan Hristić reminds us from the beginning that myth equals a fairy-tale, but that human relations, observed through the prism of everyday life, are profoundly opposite to that of a tale. Even at the very beginning, the Girl speaks about Princess Electra's grim fate, and she replies: "That manner of speaking is to be found only in fairy-tales." 26

The question is if it is possible, after having taken their revenge and after a sevenyears' lapse, that Electra and Orestes would have become like Clytemnestra and Aegisthus? Quite probably it is. "Revenge is a jolly idea, but murder is a terrible thing to do," Pylades says. ${ }^{27}$ And Marta Frajnd adds: "Revenge is, in fact, most appropriately and painlessly taken by time; it continues its deed even upon the second Orestes' leaving from Argos that marks the end of Hristić's drama." 28

In classical times, Hristić's Orestes would, most likely, have been characterized as some kind of an "inter-genre." Due to the reversed catastrophe it portrays, it could also be played as the fourth part of the tetralogy in place of a satyr play but since it is highly reflective and delicate it would not be so closely related to it. Instead, there obviously are some similarities with Euripides' happy-ending plays such as Iphigenia in Tauris, Helen and Alcestis that critics are prone to call "pro-satiric" or "para-tragedies," in which the basic "tragic" tone has been altered. ${ }^{29}$ Modus operandi, more or less parallel to the one represented in a satyr play, is to be found in the plays of our analysis too. Contrary to the other two Hristić's dramas - Clean Hands and The Seven: The Way We Would Read Them Today - that have equally been inspired by ancient myths and classical tragedy, the chorus ${ }^{30}$ is absent from Orestes. Thus, the action has become more condensed and accelerated and

\footnotetext{
${ }^{24} \mathrm{Ibid}$.

${ }^{25}$ Ibid. 348. Cf. also Milin 2004: 20-21.

${ }^{26}$ Hristić 1970: 81.

${ }^{27}$ Ibid. 109.

${ }^{28}$ Ibid. 351.

${ }^{29}$ Maričić 2008: 17-20.

${ }^{30}$ Cf. Maričić, Milanović 2016: 58-69.
} 
the play more contemporary and modern; up-to-date, just like every well-written drama always is. ${ }^{31}$ Nevertheless, its relevance is to be observed in Orestes' eagerness to persevere in forgiving. Forgiveness is something that thwarts the spiral, perpetual, vicious circle of evil. Violence always begets violence. Forgiveness is the only possible way of stopping it no matter how hard or terrifying it may seem.

Hristić's sentence in Orestes is pure, clear, his thought never wanders, punctuation marks do not disturb it. His dialogue is well balanced, minimalistic most of the time, but always functional:

ELECTRA: This is timeless, in fact. The overall time has been void since you have gone. The time is dead, never moving, always the same. It contains neither the past, nor the future or present, but only the memory. Exactly seven years have passed since then. That number does not indicate a thing to me. Maybe we should go to the cemetery, but I don't know where he lies. There is nothing under that stone. ${ }^{32}$

These words might come back and finish the play in the form of a refrain since they contain remembrance and oblivion that put its characters into motion and withhold them from acting. But oblivion is also an indispensable part of the memory. ${ }^{33}$

Under the strong impression of Hristić's drama, we still try to fathom what the role of sound in it is. According to Natalija Jelić-Jovanović in Orestes the poet achieves special effects with silences, clamour, and noise of water. The dialogues of revenge dramas are often "interrupted by silences, which slow down the action and calm down the passions, giving thus a special tone to the entire play." 34

With the sound effects Jovan Hristic tries to illustrate that the heroes of his plays are not isolated, but part of the entire community, residents of the city of Argos. Being always in harmony with the events of the play, murmur is enhanced or diminished. This "external influence," the daily life of the city, makes the play more human, moving it away from the bloody and tragic plot and the ordeal its heroes are experiencing: "Murmur intensifies. Sounds of the green market," or "Murmur. Cries of sellers," to mention only a few notes we read in the Didascalia of Orestes. ${ }^{35}$ Then suddenly soldiers appear on the scene dispersing citizens and freeing the space for the royal couple to pass. This is the moment when we think that a conflict is about to take place; at the same time we expect the characters to put

\footnotetext{
${ }^{31}$ Maričić 2006: 588-589.

${ }^{32}$ Hristić 1970: 81.

${ }^{33}$ There is an analogy of Hristić's thoughts on memory and oblivion as well as on the perception of time found by Natalija Jelić-Jovanović 2010: 55 in T.S. Eliot's poetic work Four Quartets:

Time present and time past

Are both perhaps in time future

And time future contained in time past (Burnt Norton, I, 1-3);

In my beginning is my end (East Coker I, 1);

What we call the beginning is often the end

And to make an end is to make beginning (Little Giding, V, 1-2).

http://www.davidgorman.com/4Quartets/notes.htm.

It is noteworthy adding that in 1963 as the editor in Prosveta, Belgrade's famous publishing house of the time, Jovan Hristić published a book of T. S. Eliot under the title Selected texts, translated by Milica Mihailović.

${ }^{34}$ Hristić 1970: 68.

${ }^{35}$ Ibid. $86,87$.
} 
on their tragic masks, for, as we read in the Didascalia "a tumult suddenly dies out." 36 However, this scene is followed only by a short and isolated burst of Orestes' anger: "To free space! To clear out of here! So that they can pass! They." 37 Then, suddenly everything quiets down, again: "Street murmur again, then silence," 38 as is stated in another Didascalia.

Such a reversal approach that actually betrays our expectations is quite common in Orestes as if Hristic suggests that the end of the play is supposed to be equally unexpected.

The sound of the water and the slaps of the barefoot Aegisthus are heard often in the play. ${ }^{39}$ Aegisthus, Clytemnestra's accomplice in the murder of Agamemnon, takes a bath quite often revealing thus his desire to wash the blood and guilt from his hands, while it conveys some other symbolic ${ }^{40}$ values as well.

Orestes is a memorable radio drama. The Drama. Remarkably written, it tells a universal story, universal in a sense that it could be read as an alternative version of the myth of Orestes and Electra, a myth recomposed so many times in literary history and criticism.

On the other hand, hatred, much more concrete and palpable than love, maybe most of the time, triumphs in Velimir Lukić's Medea. This radio drama performed in 1962 was written with an exceptional poetic drive and dramaturgic endowment. Medea, convincingly following the path of Euripides' tragedy, seems to have originated from Jason's lines which are directed towards the heroine Medea in the aforementioned tragedy:

You are famous; if you still lived at the ends of the earth
Your name would never be spoken. Personally, unless
Life brings me fame, I long neither for hoards of gold,
Nor for a voice sweeter than Orpheus'! (Euripides, Medea 539-44). ${ }^{41}$

Similarly, at the beginning of the play, Lukić's Medea says:

MEDEA: What do you think, Nanny, how can I take revenge

On Jason the unfaithful? On that damned husband,

The man of greed, whose mind got obscured by fame.

He sees no more due to his ambition

Of a beast, and he forgets all about love, children, marriage,

All that is sacred and precious, all for the sake of gaining some

Silly honours as such is to be called king's son-in-law. ${ }^{42}$

But some lines later, Jason confirms that:

JASON: To have a wife is not an achievement to a Greek man.

His goal is fame. For name is what remains, chiselled in the stone. ${ }^{43}$

${ }^{36}$ Ibid. 88 .

${ }^{37}$ Ibid.

${ }^{38}$ Ibid. 89.

${ }^{39}$ Ibid. 86, 93, 95, 102, 106, 107, 108, 114.

${ }^{40}$ Cf. Gerbran, Ševalije [Gheerbrant, Chevalier] 2004: passim.

${ }^{41}$ Philip Vellacot's translation of the 1963 Penguin edition.

${ }^{42}$ Euripid, Anuj, Lukić, 2009: 99.

${ }^{43}$ Ibid. 113. 
The gap between Greeks and the barbarians is insurmountable. Jason and Medea have been overcoming it by love, but when Jason betrays her, Medea's hatred gets inflamed; hatred that grows even bigger since it contains all the scorn and disgust that a "savage barbarian woman" and a stranger could feel towards the Greeks and their way of life, the Greeks who, as Medea puts it, justify crimes and mitigate them by their culture, amphorae, statues, and dramas, the Greeks whose fickleness she despises. Jason, Aegeus, Nanny, a Chorus of Corinthian girls and a Chorus of Athenians all speak about the change and justify the temporariness. However, after having committed the crime, blasphemous Medea says: "Death alone brings change and silence." 44 Medea's "absolute love" loses its battle with the fickleness of Greek nature. She, the barbaric woman, "brought up to love only once," would not accept what other Greek women would:

NANNY: Look around, the place is full of Hellenic wives that have accepted the haughty face of their husbands. ${ }^{45}$

And when Jason and Nanny tell her that her sons will resemble their father and put their trust only in him, Medea decides to kill them: "I would rather throw my sons to dragons than bring them up as Hellenes!" 46

Motifs that lead to a child slaughter make Lukić's Medea different from Euripides'. Consequently, Lukić's Medea decides more promptly to commit the crime. It might seem that the pace and duration of the radio drama influences that velocity, but the decision is equally well-motivated and painful as is the original one:

MEDEA: That blood will cause me pain more than anyone could ever imagine.

I do not fear anyone's anger as I do my own solitude

When it is their screams I shall remember

And those fragile necks whose blood is to be shed. ${ }^{47}$

Lukić's Medea tries to end her solitude once again: Athenian king Aegeus offers her a shelter and a bed. However, he throws her away as he satiates his lust for her. ${ }^{48}$ Medea punishes the newly-emerged Greek fickleness with a fresh murder. She comes to Jason afterwards. They both have changed. Jason is crushed by the death of his children, his new bride and his father-in-law; deaths that accentuated the worthlessness of his former fame:

JASON: Isn't this change but a negligence

That my forefathers the Hellenes have planted in me,

the essence of this world and its ways?

If nothing valuable will abide for eternity,

\footnotetext{
${ }^{44}$ Ibid. 107.

${ }^{45}$ Ibid. 102 .

${ }^{46}$ Ibid. 114.

${ }^{47}$ Ibid. $119-120$.

${ }^{48}$ Let us remember that in the original mythical story, Medea asks Aegeus to give her shelter, promising him an heir in exchange. Aegeus marries her and she gives him son, called Medus. However, when she tries to poison Theseus, Aegeus chases her away from Athens.
} 
Resigned, he gets drunk during day-time and has conversations with his dead sons and Medea at night. He says he has killed for fame and out of boredom, while, on the contrary, Medea killed in order to defend her world since the desires of her lust, love and revenge were telling her that her thinking was correct. ${ }^{50}$ But that was the case once. Now, Medea has implemented in her barbarian nature the Greek desire of fame. She knows one can "wane by grief for a myriad times; grief, caused by a warm-hearted love" but that it would be to no avail. Nevertheless, "a five corps' poison" is sufficient to be remembered upon. Poets will sing of her revenge and Jason will be a living witness to it: "If only you could hate me and every day commemorate me." 51

Not a trace of love abides in her, love that Jason hopes to find. He, as well as Aegeus, used to call her a fruit, a pomegranate one suckles, and then throws away.

MEDEA: A fruit, senseless but useful fruit they profited from, and then threw away and forgot about; the fruit that left a bloody trace behind... ${ }^{52}$

These are the very words of Medea, depicting herself from her own point of view.

Jason does not take up his spear; instead, he sees Medea off with the words: "You do not exist anymore, since you became just like me." 53

And finally Velimir Lukić ends his drama with the following dialogue:

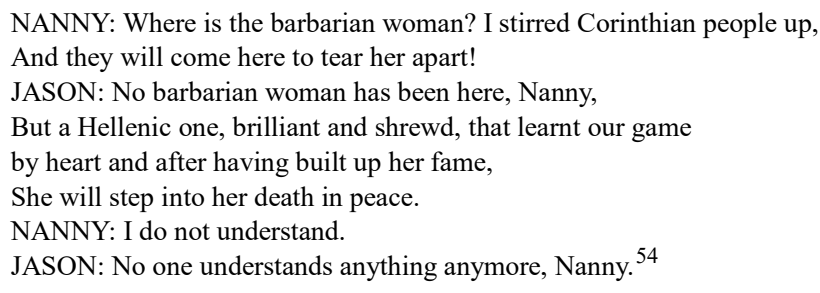

It would be interesting to read and listen to a drama in which Medea, just like Hristić's Orestes, has not taken her revenge, but simply left Corinth with her sons. How would the time take its revenge on treacherous Jason?

When we speak of the characters, one cannot but notice the absence of Euripides' Teacher in Lukić's play, not to mention that his Chorus of Corinthian girls as well as the one of Athenians, scrutinize, interpret, conclude and transmit the action further on. Euripides' Creon is more powerful, self-conscious, decisive, but more fearful in Lukić's drama. Nevertheless, he magnificently minimalistically characterizes Medea with the one and only

\footnotetext{
${ }^{49}$ Ibid. 129.

${ }^{50}$ See Euripid, Anuj, Lukić 2009: 133.

${ }^{51}$ Ibid. 139.

${ }^{52}$ Ibid. 136

${ }^{53}$ Ibid. 140 .

${ }^{54}$ Ibid. 140.
} 
line:"Your brain is too swift, your love sincere, but your vanity immortal." 55

In his bitter anthology (that proved to be his last) entitled Budne senke tame (The Wake Shades of Darkness), Velimir Lukić turns back to Medea and her deed in his poem ${ }^{56}$ "Predskazanja" ("Predictions"):

Upon putting Colchidian dragon to sleep,

Medea, in spite of her second sight,

Failed to grasp that thus she has just opened the gates

To her horrific undeath

More fearsome than the very dying.

Why did the wind in Colchidian gardens

Weep in a childish voice -

She carelessly failed to ask herself

Medea, the beloved and the cursed. ${ }^{57}$

As far as the other characters in the drama are concerned, Nanny's is one of the most expressive in Lukić's drama. Compared to the kind and pious Nanny in Euripides, the old compassionate woman portrayed by Velimir Lukić is shaped into a genuine Greek patriot who, at the end, stirs Corinthians up against Medea. Jason is depicted as arrogant both by the Greek and the Serbian poet. In Euripides, he tries to hide his ambition and greed under the veil of his concern for the children, while in Lukić, he is a "love usurer," and almost completely unscrupulous at the beginning - compelled by Creon's wine, he comes to Medea not to justify himself but to laugh at her. Both characters are equally crushed by the tragedy. Therefore, in the same mode, a third Jason should be joined to the aforementioned two, the one from Jean Anouilh's Medea. His Medea is not only a deceived woman, but authentically evil as well. When Jason is about to marry another, the Colchidian sorceress does not desire him any longer, but she does not want to abandon him for Creusa either. Jason wants to free himself from everything that binds him to Medea - he does not think of power and fame at all - and wants to make a clean start in a modest and simple way by putting his hopes in good fortune:

Je veux être humble. Ce monde, ce chaos où tu me menais par la main, je veux qu'il prenne une forme enfin. C'est toi qui as raison sans doute en disant qu'il n'est pas de raison, pas de lumière,

\footnotetext{
${ }^{55}$ Ibid. 107.

${ }^{56}$ Many of Lukić's dramatic characters appear in his poems as well. Filoktet (Philoctetes) of the anthology Madrigal i druge pesme (Madrigals and Other Poems, 1967) appears to be announcing the drama of the mythical archer I smrt dolazi na Lemno (Death Comes to Lemnos, 1970). Lukić published Iphigenia in Književne novine on 28 July 1961, which would some time later, modified to a certain extent, represent the final monologue of Kalhas the prophet in the drama Okamenjeno more (The Petrified Sea). The Anthology Budne senke tame (The Wake Shades of Darkness) also contains a poem "Neposlato pismo Lucija Aneja Seneke" ("Unsent Letter of Lucius Anneus Seneca"), which could stand for an untold monologue of a stoic and a tragic hero on his deathbed of the drama Zavera ili dugo praskozorje (Conspiracy or the Long Daybreak). In the epilogue "U traganju za Itakom" (Searching for Ithaca) of Lukić's poetry book Rub (Borderline) Slobodan Rakitić says: "Successful lyric poems always remind us of dramatic monologues in many features. Likewise, numerous Lukić's poems have features of dramatic monologues; as if they have been taken from one of his dramas..." Lukić 1982: 73.

${ }^{57}$ Lukić 1994: 72.
} 
pas de halte, qu'il faut toujours fouiller les mains sanglantes, étrangler et rejeter tout ce qu'on arrache. Mais je veuxm'arretêr, moi, maintenant, être un homme. Faire sans illusions peut-être, comme ceux que nous méprisions; cequ'ont fait mon père et le père de mon père et tousceux qui ont acceptéavant nous, et plus simplement que nous, de déblayer une petite place où tienne l'homme dans ce désordre et cette nuit. ${ }^{58}$

The lyrical dialogue in which Medea and Jason are questioning their love is imaginative and strong, just like the whole Anouilh's play. He speaks about great love between two people that vanished through time, but also about Medea's wicked vanity that prepared a blood feast upon the remnants of love.

However, Lukić's drama is interwoven with Heraclitus' philosophy stating that the only everlasting phenomenon is change itself. All the Greeks have been led and their deeds justified by this thought. ${ }^{59}$ Poets themselves represent the instrument of that "philosophy of change." Medea is firstly disgusted with them ("heartless bards"), but afterwards, "upon having become a Hellenic woman," she accepts the fact that they are those who are to spread the news of her "bloody fame":

MEDEA: And then your poets will engender their hexameters

And sing of Medea's ugliness,

And mention her name forever and ever. ${ }^{60}$

Pessimistic feelings and view of the world prevail in Velimir Lukić's dramas and poetry. His characters lose on a regular basis in collision with the world, with power and with their own nature. The only possibility is to preserve one's own dignity in death (such as Iphigenia in Petrified Sea) or by paying off a shameful life (as Scevinus in Conspiracy or the Long Daybreak and Publius in Evil Night). Oedipus, on the other hand, as a victim of gods' plot in the Theban Plague, refuses even death and thus remains a "groundless God."

Lukić's story of Medea's bloody fame is echoing, painfully updated, in our reality and our time that creates and spreads legends of criminals, resolutely striving to reshape our memories. ${ }^{61}$

\footnotetext{
${ }^{58}$ Anouilh 1953: 70.

${ }^{59}$ One cannot avoid mentioning this leading motif of an everlasting change in Herodotus' Histories depicted in several excursuses such as is the one with Croesus who, being put on a pyre, cried out Solon's name three times and only at the time of his death experience he understood Solon's words stating that no one should be considered fortunate before his end (Hdt. 1.86.3-4). The same motif of the fickle fate is so powerfully expressed in Chorus's words that echo though centuries in the final verses of Oedipus Tyrannus (1526-31): "See into what a stormy sea of troubles he (sc. Oedipus) has come! Therefore, while our eyes wait to see the final destined day, we must call no mortal happy until he has crossed life's border free from pain.” (English trans. by Sir R. Jebb of the 1887 Cambridge edition).

${ }^{60}$ Euripid, Anuj, Lukić 2009: 137.

${ }^{61}$ In the interview with Slobodan Kostić, a respectable Croatian film director Rajko Grlić, commented on fate and drama in "Yugoslav" circumstances: "One cannot but notice that the premiere of Karaula (The Border Post) took place after Slobodan Milošević (b. 1941, d. 2006), Franjo Tuđman (b. 1922, d. 1999) and Alija Izetbegović (b. 1925, d. 2003) - those who led the three peoples into the Yugoslav clashes - were finally gone from the political and life scene... But I am afraid that people here, even after their departure, have not yet seen the third act of their drama. We always start with the hope to reach a Utopia. In the second act - as Miroslav Krleža once said - happens the curse of the dreams that are coming true. Every transfusion of dreams into life usually proves
} 


\section{Conclusion}

The recent ${ }^{62}$ Jan Fabre's 24 hour spectacle Olympus - a mix of all ancient dramas proves how ancient myth is "alive and kicking" capable of shaking and shocking us today in order to pass a message in accordance with the concept of the contemporary theatre, the concept which was actually the same from the period of the genuine tragedies. That is why Hristić's and Lukić's radio plays should be recorded again and aired in line with the worldwide tendency of history repeating itself or they should be even staged. Hristićs Orestes will teach us how to love and forgive and Lukić's Medea will warn us not to stain our hands with blood for fame, underlining the meaninglessness of the very act of revenge. Finally, both radio dramas show that our time is in need of constant dialogue with the past, no matter if it is remembered as a historical or mythical one.

\section{ANCIENT SOURCES:}

Euripides. Medea and other plays: Medea, Hecabe, Electra, Heracles, translated with an Introduction by Philip Vellacot. Harmondsworth: Penguin Books, 1963.

Herodot. Istorija 1, 2, trans. into Serbian and notes by Milan Arsenić. Novi Sad: Matica srpska, 1988.

Sophocles. The Oedipus Tyrannus of Sophocles. Edited with introduction and notes by Sir Richard Jebb. Cambridge: Cambridge University Press, 1887.

\section{REFERENCES:}

Anouilh, Je. Medée. Paris: La Table Ronde, 1953.

Belli, A. Ancient Greek Myths and Modern Drama. A Study in Continuity. New York - London: New York University Press - University of London Press Limited, 1969.

Euripid, Ž. A. Velimir L. Tri Medeje [Euripides, J. Anouilh, V. Lukić, Three Medeas], Beograd: Paideia, 2009.

Finci, E. Više i manje od života, Utisci iz pozorišta IV, Beograd: Prosveta, 1965.

Frajnd, M. 'Apokrifi Jovana Hristića', Književna istorija, 14, 1971, 338-356.

Gerbran, A. Ševalije, Ž. Rečnik simbola [Alain Gheerbrant et Jean Chevalier, Dictionnaire des symmboles, Serbian edition ]. Novi Sad: Stylos, 2004.

Highet, G. The Classical Tradition, Greek and Roman influence on Western Literature. New YorkOxford: Oxford University Press, 1985.

Hristić, J. 'Skica za fotobiografiju', in: S. Gordić and I. Negrišorac(eds.), Poezija Jovana Hristića, zbornik radova, Novi Sad: Matica srpska, 1997, 103-140.

to be very bloody around here. Instead of leading to final solutions, all actions are somehow cut without any catharsis and with no final scene. The corpses are not being carried out in the final act, nor are they followed by the final words. Here heroes simply vanish, things are somehow put into a phenomenal order and nobody wants to think any more about the things that happened in the first and second acts until someone, fifty years later, comes up with an idea to bring to mind all those unfinished acts and to start stirring them. This seems to be the curse of this region of ours." Slobodan Kostić, "Arheologija bivših života" (Archeology of Past lives), Vreme 794, p. 23 March 2006, http://www.vreme.com/cms/view.php?id=447329> (accessed 6 March 2017).

${ }^{62} 51^{\text {st }}$ BITEF: 23 September 2017. 
Hristić, J. Čiste ruke: drama u tri čina. Beograd: Jugoslovensko dramsko pozorište, 1960. . 'Antički mit i savremena drama', Scena, 3, 1969, 197-202. . Četiri apokrifa. Novi Sad: Matica srpska, 1970.

. Poems, trans. by Bernard Johnson. London - Beograd: ASWA, 2003.

Jelić-Jovanović, N. Drame Jovana Hristića (unpublished master's thesis). Belgrade: University of Belgrade, Faculty of Philology, 2010.

Kostić, S. "Arheologija bivših života”, interview with Rajko Grlić. Vreme, 794, 23 March, 2006. < http://www.vreme.com/cms/view.php?id=447329> [accessed 6 March 2017]

Kott, J. Jedenje bogova, Studije o grčkim tragedijama [The Eating of the Gods. An Interpretation of Greek Tragedy. Serbian Edition], Beograd: Prosveta, 1974.

Lukić, V. Okamenjeno more, Beograd: Prosveta, 1962. . Madrigali i druge pesme, Beograd: Prosveta, 1967.

. I smrt dolazi na Lemno, Beograd: Nolit, 1987.

. Zavera ili dugo praskozorje, Novi Sad: Sterijino pozorje,1974.

. Rub, Beograd: SKZ, 1982.

. Budne senke tame, Beograd: Prosveta, 1994.

Marjanović, P. Srpski dramski pisci XX stoleća, Novi Sad - Beograd: Marica srpska, Akademija umetnosti - Fakultet dramskih umetnosti, 1997.

. 'Dva neoklasicistička dramatičara (Jovan Hristić: Čiste ruke, Velimir Lukić: Dugi život kralja Osvalda)', Zbornik radova Fakulteta dramskih umetnosti 2, 1998, 93-116.

Maričić, G. 'Mitske priče na radio talasima: Hristićev Orest i Lukićeva Medeja', Zbornik Matice srpske za književnost i jezik, 54 (3), 2006, 585-593.

. Satirska drama danas: teorija ili teatar? [Satyr Play Today: Theory or Theatre?]. Beograd: NNK Internacional, 2008.

Maričić, G. Milanović, M. 'The Tragic Chorus in Ancient Times and Nowdays: its role and staging', Istraživanja, 27, 2016, 58-69.

Milin, B. 'O Hristićevoj raskoši tišine', Program for the play "Terasa”, Beograd: Jugoslovensko dramsko pozorište, 2004, 20-21.

Palavestra, P. Bećković, M. Simović, Lj. Čini nam čast i zadovoljstvo... Skupština za izbor novih članova SANU, Odeljenje jezika i književnosti. Beograd, 1997.

Radisavljević, Z. 'Generacija darovitih reditelja', interview with Jovan Hristić, Politika (20 Jun), 1998, 17. 


\title{
ГОРДАН МАРИЧИТ
}

Универзитет у Београду

Филозофски факултет, Одељење за класичне науке

\author{
ИФИГЕНИЈА РАДУЛОВИЋ \\ Универзитет у Новом Саду \\ Филозофски факултет, Одсек за историју \\ ЈЕЛЕНА ТОДОРОВИТ \\ Универзитет у Београду \\ Филозофски факултет, Одељење за историју
}

\section{ДВЕ РАДИО ДРАМЕ О ЉУБАВИ, МРЖЫИ И ОСВЕТИ}

\section{Резиме}

Аутори рада обрађују два античка мита везана за љубав и мржњу, испричана на савремени начин у две радио драме Јована Христића и Велимира Лукића, истакнутих српских, односно југословенских драмских писаца из друге половине $\mathrm{XX}$ века. Христићев Орест и Лукићева Медеја баве се темом освете, остварене/извршене и неостварене/неизвршене, дајући нам једну нову интерпретацију Еурипидових познатих трагедија, које су много пута рекомпоноване и декомпоноване у књижевној хипертекстуалној историји и критици. Питање освете у ове две радио драме преплиће се с односом љубав-мржъа. У модерном Оресту и Медеји, то питање и тај однос дати су на потпуно другачији начин у поређењу са оригиналним Еурипидовим трагедијама, тако да се Христићев Орест на крају не свети, док Лукићева Медеја ипак врши одмазду с драматичним последицама.

Транспоновани у свет античког мита који је и део наше „надреалне стварности“, само захваљујући звуку, усредсређени једино на оно што чујемо и осећамо, слушаоци катарзично усвајају горку лекцију живота и историје о бесмислености славе и освете, истовремено прихватајући да праштају, али не и да заборављају. Недавна двадесетчетворочасовна Фаброва представа Олимп указује на то колико је антички мит жив, а наше две радио драме које поново треба преслушати и наново снимити, а зашто не и поставити на сцену, доказују да савремено доба има сталну и незаустављиву потребу за дијалогом с прошлошћу, без обзира на то да ли је она историјска или митска.

Кључне речи: антички мит, љубав, мржња, освета, радио драма, Opecm, Meдеја. 